\title{
PENDIDIKAN POLITIK : SARANA DAN PELAKSANANNYA
}

\section{Oleh:}

\section{NORSANTI}

\begin{abstract}
This writing aims to explore understanding about political education that include means and its implementation in this state. Political education is a learning to raise political knowledge and develop political awareness of society. Political awareness is an observation about politics problem of the world with a certain point of view. The implementation of political education in Indonesia still face many obstacles because the institution that has role to realize political education for society still not maximal to realize its role in process to educate society politically.
\end{abstract}

Key words : political education, means, implementation.

\section{A. Pendahuluan}

Dalam kehidupan bermasyarakat dan bernegara, manusia tidak bisa melepaskan diri dari yang namanya politik, minimal mereka menjadi objek yang diterapkan atas mereka berbagai kebijakan politik. Fakta ini digambarkan oleh seorang pakar ilmu politik, Prof. Dr. Ramlan Surbakti bahwa -kita tidak bisa lepas dari politik, baik secara sengaja atau tidak sengaja terlibat dalam kehidupan bermasyarakat”. Jadi, manusia dalam kehidupannya akan selalu melakukan interaksi politik dengan orang lain untuk memenuhi kebutuhannya dalam kedudukannya sebagai warga negara. (Riyan, 2008: 4)

Namun pada faktanya, masih banyak masyarakat yang enggan untuk berbicara bahkan terlibat dalam - politik\|. Hal ini disebabkan oleh pemahaman masyarakat tentang politik masih banyak yang keliru, banyak yang beranggapan bahwa politik itu -kotor" sehingga harus dihindari. Sekarang ini, politik hanya diartikan sebagai cara memperoleh jabatan dalam pemerintahan sehingga untuk mencapai tujuannya itu politikus sering menggunakan segala cara untuk meraih kekuasaan termasuk menyuap masyarakat agar memilihnya. Padahal, jauh lebih luas dari pada itu, politik adalah pemeliharaan atau pengaturan urusan masyarakat baik di dalam atau luar negeri yang dijalankan oleh negara atau pemerintah bersama-sama dengan masyarakat.

Selain itu masyarakat juga menganggap bahwa sistem politik itu bukan urusan mereka melainkan urusan pemerintah sehingga mereka cenderung tidak peduli bahkan tidak mau terlibat dalam urusan politik. Kalaupun mereka terlibat dalam aktivitas politik itupun hanya sebatas pada saat pemilu dengan memilih penguasa dan para wakil rakyat yang tidak jarang pilihan mereka bukan didasarkan pada kemampuan atau kualitas para politikus tapi lebih karena ada uang (suap) yang sudah mereka terima.

Karena pemahaman yang sempit terhadap politik itulah, ditambah dengan realitas politik yang — kotor\| di hadapan mereka membuat masyarakat semakin sinis terhadap politik, partai politik maupun politisi. Hal itu mengakibatkan partisipasi masyarakat dalam politik semakin menurun dan masyarakat cenderung dijadikan sebagai alat para politisi 
untuk meraih kekuasaan sehingga masih ada masyarakat yang mau dibodoh-bodohi atau percaya janji-janji palsu para politisi tersebut.

Melihat realitas tersebut, disinilah diperlukan sebuah metode untuk mencerdaskan politik di tengah-tengah kehidupan masyarakat agar masyarakat tidak hanya menjadi objek politik tapi juga sebagai pelaku (subjek) politik dengan memilih penguasa yang profesional dan amanah serta melakukan aktivitas koreksi dan kontrol ketika penguasa tersebut memimpin mereka. Salah satu metode untuk mencerdaskan masyarakat dalam bidang politik adalah melalui pendidikan politik yang baik, yaitu yang benar-benar mencerdaskan masyarakat bukan malah menyesatkan.

\section{B. Rumusan Masalah}

Berdasarkan latar belakang di atas maka penulis merumuskan masalah yang akan dibahas dalam tulisan ini yaitu:

1. Apakah definisi pendidikan politik?

2. Apakah fungsi dari pendidikan politik?

3. Lembaga-lembaga apa saja yang menjadi sarana pendidikan politik?

4. Bagaimana pendidikan politik di Indonesia?

\section{Pembahasan}

\section{Definisi Pendidikan Politik}

Istilah pendidikan politik dalam bahasa Inggris sering disamakan dengan istilah political sosialization. Istilah political sosialization jika diartikan secara harfiah ke dalam bahasa Indonesia akan bermakna sosialisasi politik. Oleh karena itu dengan mengunakan istilah political sosialization banyak yang mensinonimkan istilah pendidikan politik dengan istilah Sosialisasi Politik, karena keduanya memiliki makna yang hampir sama. Dengan kata lain, sosialisasi politik adalah pendidikan politik dalam arti sempit.

Alex Thio (dalam Maran, 2007: 135) menyatakan sosialisasi (pendidikan) politik adalah proses dengan mana individu-individu memperoleh pengetahuan, kepercayaankepercayaan dan sikap politik. Melalui sosialisasi politik, individu diharapkan mau dan mampu berpartisipasi secara bertanggung jawab dalam kehidupan politik. dalam hal ini sosialisasi merupakan suatu proses pedagogis (proses pendidikan) atau suatu proses pembudayaan insan-insan politik.

Selain itu Hyman (dalam sjamsuddin, 2001: 3.2) menyatakan bahwa sosialisasi politik adalah suatu proses penyerapan nilai dari lingkungan sistem politik ataupun dari masyarakat terhadap individu atau masyarakat secara keseluruhan.

Rusadi Kantaprawira (2006: 55) menyatakan bahwa pendidikan politik adalah upaya untuk meningkatkan pengetahuan politik rakyat dan agar mereka berpartisipasi secara maksimal dalam sistem politiknya. Pada pokoknya, rakyat perlu pendidikan politik secara kontinu (berkesinambungan) atas dasar nilai-nilai tertentu agar masyarakat dapat terus meningkatkan pemahamannya terhadap masalah politik yang selalu mengalami perkembangan. Masalah pendidikan politik adalah masalah yang kompleks, bersegi banyak, berubah-ubah dan karena itu memerlukan pemikiran yang mendalam sehingga sangat diperlukan adanya pendidikan politik yang berkesinambungan (kontinu).

Berdasarkan beberapa pengertian di atas dapat disimpulkan bahwa pendidikan politik adalah suatu proses pembelajaran untuk meningkatkan pengetahuan politik dan membangun kesadaran politik masyarakat. Adapun kesadaran politik adalah pengamatan terhadap persoalan politik dunia dengan sudut pandang tertentu. 


\section{Fungsi Pendidikan Politik}

Dalam sebuah negara, pendidikan politik memegang peranan penting sebab pendidikan politik akan mampu meningkatkan pengetahuan dan pemahaman masyarakat tentang kehidupan politik. Dengan semakin meningkatnya pengetahuan dan kemampuan masyarakat, maka pada gilirannya akan mendorong timbulnya kesadaran politik secara maksimal dalam suatu sistem politik di negara tersebut.

Pendidikan politik berfungsi untuk memberikan isi dan arah serta pengertian kepada proses penghayatan nilai-nilai yang sedang berlangsung. Ini berarti bahwa pendidikan politik menekankan kepada usaha pemahaman tentang nilai-nilai yang etis normatis yaitu dengan menanamkan nilai-nilai dan norma-norma yang merupakan landasan dan motivasi masyarakat dalam berpolitik.

Merujuk pada beberapa pengertian pendidikan politik yang telah disebutkan di atas, maka pendidikan politik mempunyai dua fungsi. Pertama, fungsi pendidikan politik adalah untuk mengubah dan membentuk tata perilaku seseorang agar sesuai denga tujuan politik yang dapat menjadikan setiap individu sebagai partisipan politik yang bertanggung jawab. Kedua, fungsi pendidikan politik dalam arti yang lebih luas untuk membentuk suatu tatanan masyarakat yang sesuai dengan tuntutan politik yang ingin diterapkan.

Inti dari pendidikan politik adalah mengenai bagaimana masyarakat direkrut dan disosialisasikan. Jadi, fungsi dari pendidikan politik adalah untuk menjelaskan proses perekrutan dan upaya sosialisasi kepada rakyat untuk mengerti mengenai peranannya dalam sistem politik serta agar dapat memiliki orientasi kepada sistem politik.

Fungsi yang disampaikan di atas lebih menonjolkan fungsi pendidikan politik dalam mengubah tatanan masyarakat yang ada menjadi lebih baik dan lebih mendukung tercapainya proses politik yang sehat. Sedangkan fungsi pendidikan politik bagi individu antara lain adalah:

a. Peningkatan kemampuan individual supaya setiap orang mampu berpacu dalam lalu lintas kemasyarakatan yang menjadi semakin kompleks;

b. Agar masyarakat memahami mekanisme politik serta ikut mengendalikan dan mengontrol pelaksanaan politik di masyarakat.

\section{Sarana Pendidikan Politik}

Menurut Ruslan lembaga-lembaga pendidikan politik terdiri dari lembaga formal dan informal. Keluarga, sekolah, partai-partai politik dan pressure group, media massa dengan segala jenisnya merupakan sarana-sarana pendidikan politik yang paling esensial. Peran yang dapat dimainkan oleh lembaga-lembaga tersebut dalam pendidikan politik dapat diuraikan secara ringkas sebagai berikut:

a. Keluarga

Keluarga merupakan lembaga pendidikan politik yang paling utama dan paling urgen selama masa anak-anak. Keluarga memainkan peran fundamental dalam hal ini. Pengaruh yang paling nyata adalah bagaimana keluarga dapat membangun afiliasi dan loyalitas politik dasar anak-anaknya, membentuk rambu-rambu dasar kepribadian yang nantinya akan memberikan kontribusi dalam menumbuhkan orientasi politik anak-anak dan mengembangkan kesadaran serta pemikiran politik mereka. Keluarga juga berperan dalam membangun persepsi politik yang nantinya akan berperan dalam membentuk kesadaran politiknya sebagai warga negara.

b. Sekolah dan Perguruan Tinggi 
Sekolah dan Perguruan Tinggi berpengaruh besar dalam pendidikan politik generasi muda. Hal ini tidak lain karena di sekolah dan perguruan tinggi, nilai-nilai politik bisa diturunkan secara langsung atau tidak langsung oleh pendidik kepada anak didiknya. Sekolah dan perguruan tinggi memainkan peran tersebut melalui:

Pertama, pengajaran politik. ini dilakukan dengan memberikan pengetahuan politik kepada anak didik melalui mata pelajaran atau mata kulia tertentu.

Kedua, karakter sistem sekolah. Suasana umum di sekolah dengan sistemnya, memainkan peranan penting dalam membentuk sensitivitas anak didik terhadap dinamika politik dan mengarahkan pandangan mereka terhadap bangunan politik yang ada. Untuk membentuk sensitivitas siswa tentunya sekolah harus membangun kepedulian anak didik terhadap situasi politik di negara ini dengan mengajak mereka mengikuti berbagai peristiwa politik yang ada.

c. Partai politik dan Pressure Group (Kelompok Penekan)

Partai politik lebih dari sekedar alat pemilu atau perkumpulan yang mengartikulasikan sikap politik bagi kelompok masyarakat, namun ia memainkan peran besar dalam pendidikan politik. Melakukan pendidikan politik merupakan salah satu tugas penting parpol. Sebuah parpol yang memiliki tanggung jawab yang besar terhadap rakyat, pasti melakukan pendidikan politik. Parpol yang melakukan pendidikan politik sama dengan memberikan perhatian pada rakyat, karena parpol tersebut berupaya untuk tidak membodohi rakyat dengan cara mengajak rakyat supaya memilih pilihan politiknya bedasarkan kesadaran yang murni bukan dengan kesadaran palsu yang biasanya muncul dari hasil paksaan atau tipu daya dari menyuap rakyat atau membangun citra politik di media massa.

Kelompok penekan (pressure group) seperti berbagai LSM juga berperan dalam membina kesadaran politik masyarakat melalui tekanan yang diberikan terhadap berbagai kebijakan pemerintah yang tidak sesuai dengan kepentingan masyarakat. Partai politik dan pressure group, sampai pada batas tertentu memainkan perannya dalam pendidikan politik melalui:

1. Pengajaran politik yang benar. Partai politik mengajar atau mendidik masyarakat dengan pemikiran politik yang diemban oleh partainya agar muncul kesadaran politik masyarakat. Untuk itu partai politik harus memiliki pemikiran politik ideologis yang tidak gampang dipengaruhi oleh berbagai kepentingan kelompok atau individu. Hal ini dilakukan dengan mengadakan berbagai pertemuan (pengkajian) politik, muktamar, program training (pelatihan) politik, serta publikasi pandangan politik partai terhadap berbagai fenomena politik yang berkembang melalui berbagai buletin atau majalahnya.

2. Pemberian kesempatan untuk partisipasi politik secara teratur dalam bentuk yang lebih kontinu. Partai politik dan pressure group merupakan organisasi yang tentunya memiliki tujuan, visi misi dan program kerja yang jelas sehingga aktivitas politik yang dilakukan akan lebih terarah dan kontinu dibandingkan dengan masyarakat hanya bergerak sendiri.

3. Partai politik merupakan media penyiapan dan pelatihan bagi individu untuk berani mengambil keputusan dan berpikir independen mengenai berbagai masalah umum, serta kemampuan untuk bersikap kritis. Dengan pembinaan yang terarah dalam partai politik tentunya akan menghasilkan kader-kader politik yang siap terjun dalam dunia politik.

d. Media Informasi dan Komunikasi Politik 
Yang dimaksud dengan informasi adalah berbagai berita, fakta, pemikiran dan pandangan yang diungkapkan baik secara langsung dalam kerangka yang objektif, jauh dari ambisi dan interest tertentu dengan menggunakan instrumen dan sarana-sarana yang netral. Penyampaian informasi ini bertujuan untuk memberikan kesempatan kepada setiap orang untuk menyikapi berbagai berita, fakta, pemikiran dan pandangan orang lain, agar mampu membangun pandangan yang khas baginya dan memungkinkan untuk mengambil sikap yang dianggap tepat. Media-media informasi yang mempunyai pengaruh kuat adalah radio, televisi, media cetak, buku, mimbar-mimbar mesjid, lembaga-lembaga ilmiah dan media-media lain yang ada di sekitar masyarakat.

\section{Pendidikan Politik Di Indonesia}

Dalam wajah pendidikan politik bangsa kita setidaknya ada dua bentuk pendidikan politik, yaitu pendidikan formal dan pendidikan informal. Pendidikan politik secara formal ini telah diperkenalkan di sekolah hingga perguruan tinggi, terutama sekolah atau perguruan tinggi jurusan sosial politik. Di sekolah, pengetahuan dasar politik diberikan kepada anak didik dan baru pada perguruan tinggi lah pendidikan politik akan diberikan secara sistematis dan rinci.

Dalam pendidikan politik, sekolah berperan untuk memberikan pengajaran politik dan pembentukan sensitivitas anak didik terhadap dinamika politik. Akan tetapi tidak semua sekolah memberikan pengajaran politik kepada siswanya, biasanya hanya sekolah dengan jurusan sosial politik yang memberikan pengajaran politik kepada anak didiknya sedangkan untuk sekolah jurusan eksak, pengajaran politik masih jarang diberikan sehingga tidak mengherankan sebagian besar siswa jurusan eksak partisipasinya dalam dunia politik cukup rendah yaitu hanya terbatas pada saat pemilu saja. Untuk membentuk sensitivitas anak didik terhadap dinamika politik, sekolah harus membangun kepedulian siswa terhadap situasi politik di negara ini dengan mengajak mereka mengikuti berbagai peristiwa politik yang ada. Namun sayang pembentukan sensitivitas anak didik terhadap dinamika politik di negeri ini belum bisa maksimal dilakukan karena siswa sudah disibukkan dengan berbagai tugas dan kegiatan ekstra kurikuler di sekolahnya.

Demikian juga di perguruan tinggi dengan jurusan sosial (politik), pendidikan politik menjadi mata kuliah wajib yang diberikan kepada mahasiswa agar mereka mempunyai pengetahuan politik yang lebih luas. Tapi sayangnya, terkadang mahasiswa menganggap pengetahuan politik yang diberikan hanya sebagai informasi sehingga tidak membawa pengaruh apa-apa terhadap dinamika politik di negeri ini. Selain itu, pendidikan politik juga masih bersifat pragmatis sehingga banyak yang terjebak dalam dinamika politik dan yang cukup memprihatinkan apabila ada sebagian mahasiswa yang awalnya proaktif dalam menyuarakan aspirasi rakyat berubah diam terhadap kebijakan pemerintah setelah mereka keluar dari dunia kampus dan duduk pada kursi pemerintahan.

Dalam konteks pendidikan informal, seharusnya kita diberikan pengajaran (pemahaman) tentang politik dengan berbagai konteksnya seperti di lingkungan keluarga, parpol, dan media informasi yang ada di masyarakat tapi dengan kondisi politik di negeri ini yang carut marut malahan membuat masyarakat diajarkan pemahaman politik yang keliru. Misalnya sudah menjadi rahasia umum bahwa setiap pemilu selalu ada money politic sehingga sebagian besar masyarakat menganggap aktivitas tersebut sebagai hal yang lumrah. Akibatnya masyarakat berpartisipasi dalam proses politik ini bukan karena kesadaran tapi lebih karena uang yang diberikan politisi. 
Pada lingkungan keluarga, sebagian besar anak belum mendapatkan pengajaran politik. Keluarga belum bisa membangun persepsi politik dan kepedulian anak terhadap dinamika politik negeri ini. Hal ini dikarenakan banyak orang tua yang belum —melek\| politik sehingga tidak mengherankan kalau mereka tidak melakukan pengenalan dan pengajaran politik pada anak-anaknya.

Selain keluarga, partai politik juga memegang peranan penting dalam pendidikan politik. Partai politik merupakan lembaga yang dibentuk oleh masyarakat untuk menyalurkan dan memenuhi aspirasinya. Salah satu peran utama partai politik adalah mendidik masyarakat agar memahami politik serta ikut mengendalikan dan mengontrol pelaksanaan politik di negaranya. Namun faktanya di negeri ini, pendidikan politik tidak sepenuhnya dijalankan oleh parpol tapi hanya dilakukan ketika mendekati pemilu dalam rangka merebut perhatian masyarakat agar memilih elit politis dari partai mereka. Kampanye yang merupakan kegiatan parpol dan anggotanya untuk menawarkan visi, misi dan program kerja peserta pemilu juga lebih banyak diisi dengan hiburan sehingga menyebabkan kurang terdidiknya masyarakat secara politik. Partai politik yang seharusnya bertugas sebagai pensosialisasi utama bentuk pendidikan politik yang sehat, justru mengajarkan politik yang -mati rasall meminjam istilah Ahmad Syafi‘i Ma'arif, yang hanya mengedepankan kepentingan partai tanpa ada sedikitpun berpihak pada kepentingan masyarakat. Realitas parpol yang semakin pragmatis dan hanya mengedepankan kepentingan partai mengakibatkan tingkat kepercayaan masyarakat terhadap parpol semakin menurun, ini terbukti dari hasil survei Lembaga Cirus Surveyors Group yang mengungkapkan hanya 9,4 \% responden yang masih percaya kepada parpol dan sisanya sebanyak 39,2 \% kurang percaya serta 40 \% tidak percaya lagi pada parpol. Hasil survey tersebut menguatkan survei sebelumnya yang dilakukan oleh Centre for Strategic and International Studies (CSIS) 16-24 Januari 2012, survei tersebut menemukan mayoritas rakyat tidak percaya lagi kepada parpol yaitu sekitar 87,4 \% dari total responden. (Sumber: detik.com, 5/1/2014 dan media ummat edisi 77, 2-15 Maret 2012)

Media informasi berperan untuk menyampaikan berita, fakta, pemikiran dan pandangan kepada masyarakat yang diungkapkan baik secara langsung dalam kerangka yang objektif, jauh dari ambisi dan interest tertentu dengan menggunakan instrumen dan saranasarana yang netral. Namun tidak semua media informasi di negeri ini menyajikan tayangan yang dapat meningkatkan pemahaman politik masyarakat karena media lebih senang mengikuti selera pasar dengan menyajikan sinetron, musik, gosip agar semakin banyak peminat media mereka yang ujung-ujungnya akan menambah iklan dan pemasukan. Bahkan Pakar Komunikasi politik, Effendi Gazali menyatakan bahwa media kita banyak dipengaruhi kepentingan bisnis, jadi sangat tergantung pada ratting dan sharing dan bagian lain yang dipengaruhi oleh politik. (Media Ummat, edisi 104, 3-16 mei 2013: 10)

Kalaupun ada media yang menyajikan tayangan yang mendidik secara politik, biasanya porsinya kecil dan kadang disusupi kepentingan pihak-pihak tertentu. Setiap hari kita diajarkan pendidikan politik pragmatis sebagaimana yang kita baca di koran atau yang kita saksikan di TV, hampir sepenuhnya menunjukkan kepada kita bahwa politik tidak lebih hanyalah persoalan kepentingan pribadi atau kelompok di dalamnya. Tidak jarang kita temukan media informasi yang dimiliki oleh para elit politik tertentu justru digunakan untuk mengkampanyekan dirinya atau orang-orang yang dari kelompoknya. Akibatnya media informasi sebagai sarana melakukan komunikasi politik juga tidak maksimal dalam melakukan perannya.

Melihat realitas pelaksanaan kedua bentuk pendidikan politik di negeri ini tidak heran banyak yang beranggapan bahwa pendidikan politik belum berhasil dalam mewujudkan masyarakat yang terdidik secara politik. Jika demikian, tentu yang menjadi permasalahan 
adalah metode dan konten pendidikan politik itu sendiri. Metode terkait langkah apa yang akan ditempuh untuk melakukan pendidikan politik bagi rakyat. Sedangkan konten (isi) berkaitan dengan pemikiran apa yang akan disampaikan dalam pendidikan politik dan ini sangat terkait dengan ideologi politik apa yang mendasari pelaksanaan politik di negeri ini baik oleh parpol, pemerintah dan lembaga politik lainnya.

Ini adalah wajah asli pendidikan politik yang diterima masyarakat setiap saatnya maka konsekuensi ini juga harus dibayar mahal oleh partai politik dengan munculnya kecenderungan masyarakat untuk berperilaku buruk dalam politik dan selebihnya apatis terhadap politik. Dari kenyataan ini menguatnya angka golput juga menjadi kenyataan yang tidak bisa dibantah bagaimana buruknya pendidikan politik kita yang dipraktekkan para politisi bangsa ini. Karena memang salah satu penyebab utama menguatnya angka golput disebabkan hilangnya kepercayaan publik terhadap praktek pendidikan politik yang diajarkan para police maker.

\section{Penutup}

\section{Kesimpulan}

Pendidikan politik adalah suatu proses pembelajaran untuk meningkatkan pengetahuan politik dan membangun kesadaran politik masyarakat. Adapun kesadaran politik adalah pengamatan terhadap persoalan politik dunia dengan sudut pandang tertentu. Secara umum, fungsi pendidikan politik adalah untuk menjelaskan proses perekrutan dan upaya sosialisasi kepada rakyat untuk mengerti mengenai peranannya dalam sistem politik serta agar dapat memiliki orientasi kepada sistem politik. Bagi individu, pendidikan politik berfungsi untuk meningkatkan kemampuan individual supaya setiap orang mampu berpacu dalam lalu lintas kemasyarakatan yang menjadi semakin kompleks dan agar masyarakat memahami mekanisme politik serta ikut mengendalikan dan mengontrol pelaksanaan politik di masyarakat.

Sarana pendidikan politik dapat berasal dari lembaga formal dan informal. Lembaga formal terdiri dari sekolah atau perguruan tinggi, sedangkan lembaga informal terdiri dari keluarga, partai-partai politik dan pressure group, media massa dengan segala jenisnya. Pelaksanaan pendidikan politik di Indonesia, masih menemui banyak kendala karena lembaga yang berperan untuk melakukan pendidikan politik terhadap masyarakat masih belum maksimal menjalankan perannya dalam mendidik masyarakat secara politik.

Melihat realitas pelaksanaan kedua bentuk pendidikan politik di negeri ini tidak heran banyak yang beranggapan bahwa pendidikan politik belum berhasil dalam mewujudkan masyarakat yang terdidik secara politik. Jika demikian, tentu yang menjadi permasalahan adalah metode dan konten pendidikan politik itu sendiri. Metode terkait langkah apa yang akan ditempuh untuk melakukan pendidikan politik bagi rakyat. Sedangkan konten (isi) berkaitan dengan pemikiran apa yang akan disampaikan dalam pendidikan politik dan ini sangat terkait dengan ideologi politik apa yang mendasari pelaksanaan politik di negeri ini baik oleh parpol, pemerintah dan lembaga politik lainnya.

\section{Saran}

Agar pendidikan politik dapat meningkatkan pengetahuan politik dan membangun kesadaran politik masyarakat, maka penulis memberikan beberapa saran yaitu:

a. Lembaga formal baik sekolah maupun perguruan tinggi harus terus berupaya untuk meningkatkan kesadaran politik anak didiknya dengan memberikan pemahaman politik yang benar dan ideologis, yang tidak hanya sebagai informasi bagi anak didiknya tapi dapat membangun kesadaran politik; 
b. Lembaga informal juga harus mengambil perannya dalam proses pendidikan politik bagi masyarakat, khususnya partai politik. Parpol sebagai lembaga edukasi politik jangan hanya mendidik kader dan rakyatnya dengan orasi dan menampilkan citra politik di media massa tapi lebih dari itu harus mendidik kader dan rakyat dengan pemahaman politik yang benar dan ideologis;

c. Pemerintah juga harus berperan dalam pendidikan politik dengan memberikan dukungan bahkan pressure agar lembaga formal dan informal (khusunya parpol) menjalankan fungsinya dalam mendidik masyarakat secara politik;

d. Pendidikan politik akan bisa dijalankan secara maksimal, apabila di negeri ini diterapkan sistem politik yang terbaik dari sang khalik yang mengetahui yang terbaik bagi manusia.

\section{DAFTAR}

\section{PUSTAKA}

Basri, Seta. 2011. Pengantar Ilmu Politik. Jogjakarta : Indie Book Corner.

Budiarjo, Miriam. 2008. Dasar-Dasar Ilmu Politik. Jakarta : PT Gramedia Pustaka Utama.

Efriza. 2009. Ilmu Politik (Dari Ilmu Politik sampai Sistem Pemerintahan). Bandung

Alfabeta.

Kantaprawira, Rusadi. 2006. Sistem Politik Indonesia. Jakarta: Sinar Baru

Algesindo. Maran, Rafael Raga. 2007. Pengantar Sosiologi Politik. Jakarta:

Rineka Cipta.

Riyan, MD. 2008. Political Quotient. Bandung : Madani Prima.

Syamsuddin, Nazaruddin dkk, 2001. Sistem Politik Indonesia. Jakarta: Universitas

Terbuka.

\section{Media Massa}

Detik.com, 5 Januari 2014.

Media Ummat edisi 77, 2-15 Maret 2012.

Media Ummat edisi 104, 3-6 Mei 2013. 
Spsutisna.blogspot.com./partai politik sebagai sarana pendidikan politik masyarakat/ Wuri aryati.blogspot.com./partai politik sebagai sarana pendidikan/ 